This document is confidential and is proprietary to the American Chemical Society and its authors. Do not copy or disclose without written permission. If you have received this item in error, notify the sender and delete all copies.

\title{
Methyl mercury formation in hillslope soils of Boreal forests - the role of forest harvest and anaerobic microbes
}

\begin{tabular}{|c|c|}
\hline Journal: & Environmental Science \& Technology \\
\hline Manuscript ID & es-2016-007628.R2 \\
\hline Manuscript Type: & Article \\
\hline Date Submitted by the Author: & 26-Jul-2016 \\
\hline Complete List of Authors: & $\begin{array}{l}\text { Kronberg, Rose-Marie; Swedish University of Agricultural Sciences, } \\
\text { Department of Forest Ecology and Management } \\
\text { Jiskra, Martin; CNRS, Geosciences Environment Toulouse, Observatoire } \\
\text { Midi-Pyrenees } \\
\text { Wiederhold, Jan; University of Vienna, Department of Environmental } \\
\text { Geosciences } \\
\text { Björn, Erik; Umeå University, Chemistry } \\
\text { Skyllberg, Ulf; Swedish University of Agricultural Sciences, Forest Ecology }\end{array}$ \\
\hline
\end{tabular}

\section{SCHOLARONE"}

Manuscripts

\begin{abstract}
This document is the unedited Author's version of a Submitted Work that was subsequently accepted for publication in Environmental Science \& Technology, copyright @ American Chemical Society after peer review. To access the final edited and published work see: https://pubs.acs.org/doi/10.1021/acs.est.6b00762
\end{abstract}




\section{Methyl mercury formation in hillslope soils of}

\section{Boreal forests - the role of forest harvest and}

3 anaerobic microbes

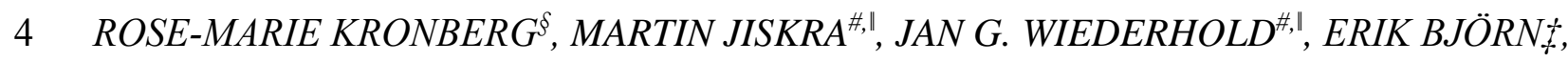

$5 \quad U L F$ SKYLLBERG ${ }^{\S^{*}}$

$6{ }^{\S}$ Department of Forest Ecology and Management, Swedish University of Agricultural Sciences,

7 SE-901 83 Umeå, Sweden. †Department of Chemistry, Umeå University, SE-901 87 Umeå,

8 Sweden "Soil Chemistry Group, Institute of Biogeochemistry and Pollutant Dynamics, ETH

9 Zurich, CH-8092 Zurich, Switzerland. "Isotope Geochemistry Group, Institute of Geochemistry

10 and Petrology, ETH Zurich, CH-8092 Zurich, Switzerland.

$12 *$ Corresponding author phone: +46 (0)90-786 84 60; e-mail: ulf.skyllberg@slu.se 


\section{ABSTRACT}

18 Final harvest (clear-cutting) of coniferous boreal forests has been shown to increase stream water

19 concentrations and export of the neurotoxin methyl mercury $(\mathrm{MeHg})$ to freshwater ecosystems.

20 Here the spatial distribution of inorganic $\mathrm{Hg}$ and $\mathrm{MeHg}$ in soil as a consequence of clear-cutting

21 are reported. A comparison of soils at similar positions along hillslopes in four 80-years-old

22 Norway spruce (Picea abies) stands (REFs) with four similar subjected to clear-cutting (CCs)

23 revealed significantly $(\mathrm{p}<0.05)$ enhanced $\mathrm{MeHg}$ concentrations $\left(\mathrm{ng} \mathrm{g}^{-1}\right), \mathrm{MeHg}$ areal masses $\left(\mathrm{g} \mathrm{ha}^{-}\right.$

$24^{1}$ ), and $\% \mathrm{MeHg}$ of $\mathrm{Hg}_{\text {тот }}$ in $\mathrm{O}$ horizons of CCs located between $1 \mathrm{~m}$ and $41 \mathrm{~m}$ from streams.

25 Inorganic $\mathrm{Hg}$ measures did not differ between REFs and $\mathrm{CCs}$ at any position. The O horizon

26 thickness or bulk density did not differ, but at CCs the groundwater table and soil water content

27 was significantly higher than at REFs. The largest difference in \% $\mathrm{MeHg}$ of $\mathrm{Hg}_{\text {тот }}$ (11 times,

$28 \mathrm{p}<0.003)$ was observed in concert with significant increases in soil water content $(\mathrm{p}<0.0002)$ at

29 intermediate hillslope positions (20-38 $\mathrm{m}$ from stream), outside the stream riparian zone.

30 Incubation experiments demonstrated that soils having significantly enhanced soil pools of $\mathrm{MeHg}$

31 after clear-cutting also showed significantly enhanced methylation potential as compared with

32 similarly positioned soils in mature reference stands. Addition of inhibitors demonstrated that

33 sulfate reducing bacteria (SRB) and methanogens were key methylators. Rates of demethylation

34 were not enhanced after clear-cutting. Our results suggest that enhanced water saturation of

35 organic soils providing readily available electron donors stimulate $\mathrm{Hg}$ methylating microbes to net

36 formation and build-up of $\mathrm{MeHg}$ in $\mathrm{O}$ horizons after forest harvest. 
40 The potent neurotoxin methyl mercury $(\mathrm{MeHg})$ is of great concern in boreal landscapes where it

41 forms and accumulates in aquatic food-webs. Concentrations of $\mathrm{MeHg}$ are high in pescivorous

42 fish and in boreal landscapes the severity of this situation seems to have increased during the last

43 decades. ${ }^{1-3}$ Because $\mathrm{MeHg}$ imported by terrestrial runoff exhibits a significantly higher rate of

44 bioaccumulation in costal sediments than in situ formed $\mathrm{MeHg},{ }^{50}$ the formation and export of

$45 \mathrm{MeHg}$ from terrestrial environments play a critical role in aquatic ecosystems.

In the 1990's it was demonstrated that $\mathrm{MeHg}$ formed in wetlands is an important source

47 of MeHg in runoff to surface waters. ${ }^{4}$ Different types of boreal wetlands have since then been

48 identified as net producers of $\mathrm{MeHg},{ }^{5,6}$ with rates of $\mathrm{Hg}$ methylation varying more than rates of

49 demethylation. ${ }^{7}$ So far Black Alder swamps is the only type of wetland shown to net degrade

$50 \mathrm{MeHg}^{8}{ }^{\text {After microbial activity was demonstrated to be responsible for } \mathrm{Hg} \text { methylation }}{ }^{9}$ several

51 microbial communities have been identified to methylate $\mathrm{Hg}$ in wetland environments, including

52 sulfate reducing bacteria (SRB), iron reducing bacteria (IRB), methanogens and firmicutes. ${ }^{10-14}$

While wetland soils are recognized as major sources, forested upland soils are generally

54 considered as sinks for MeHg. ${ }^{15}$ However, during the phase of forest harvest and time period of

55 establishment of a new stand, studies have revealed forest soils to be significant sources of

$56 \mathrm{MeHg}$ to surface waters and their biota. ${ }^{16-22}$ Yet, some studies have found little or no effect from

57 forest harvest on $\mathrm{MeHg}$ stream export. ${ }^{23}$ Clear-cutting is the most common final harvest practice

58 in boreal forests. ${ }^{24}$ It results in a loss of evapotranspiration from trees which increases both the

59 runoff and the level of the ground water table. Because of a large leaf area, this effect is greatest

60 in coniferous forests ${ }^{25}$ where the runoff has been reported to increase 48 to $107 \%$ after clear- 
61 cutting, ${ }^{21,22,25,26}$ mainly depending on the fraction of the watershed area harvested and its

62 topography (response in runoff). As a consequence of rising groundwater levels, discharge areas

63 with newly water saturated soils are extended up along lower sections of hillslopes and into local

64 depressions forming fringes and patches of new wetland-like habitats. Once inundated, the soil

65 organic matter quality of these normally well-drained forest soils may provide excellent substrate

66 as electron donors for anaerobic, $\mathrm{Hg}$ methylating bacteria. ${ }^{27,28}$ Electron donors are also provided

67 by organic debris left after clear-cutting. Soil organic matter degradation is further excelled by

68 increased exposure to solar radiation, ${ }^{29}$ which also has been shown to increase $\mathrm{Hg}^{0}(\mathrm{~g})$ photo-

69 emissions from soils after clear-cutting. ${ }^{30}$

In a recent parallel study ${ }^{22}$ to the one reported here, we showed that: (1) the organic

71 horizon MeHg soil pool $\left(\mathrm{g} \mathrm{ha}^{-1}\right)$ in average increased seven times two years after clear-cutting,

72 and (2) the stream $\mathrm{MeHg}$ export increased significantly after clear-cutting in undulating terrain.

73 An upscaling calculation demonstrated that in Sweden, where $>95 \%$ of the productive forest

74 area is managed, final harvest of boreal coniferous forest increases the $\mathrm{MeHg}$ export to aquatic

75 ecosystems by $12-20 \%$ as compared to non-harvested forests. ${ }^{22}$ This estimate, based on

76 watershed export data alone, narrows a previous one reported by Bishop et al., ${ }^{19}$ based on results

77 from a variety of studies.

To mitigate stimulatory effects of forest harvest on $\mathrm{MeHg}$ formation and stream export,

79 adjustment of forest management practices have been suggested, such as leaving zones of gallery

80 forest along streams and avoiding soil disturbance and compaction by heavy machinery. ${ }^{19,34}$

81 However, before such actions can be fully designed and implemented we need to better

82 understand processes and factors in control of $\mathrm{MeHg}$ formation in forest soil (before and after

83 harvest) and the spatial distribution of $\mathrm{MeHg}$ net producing "hot-spots" and their connections to 
84 streams. ${ }^{35}$ Here we report the effect of forest clear-cutting on the distribution of $\mathrm{MeHg}$

85 accumulated in organic soil horizons along hillslope transects, by comparing 80 -years-old

86 reference stands of Norway spruce (Picea abies L. Karst) with two-years-old clear-cuts of

87 similar stands. The potential for $\mathrm{MeHg}$ formation and degradation in soil of clear-cuts and

88 reference stands was further examined in incubation experiments where rate constants for

89 potential $\mathrm{Hg}$ methylation and $\mathrm{MeHg}$ demethylation, $k_{m}$ and $k_{d}$, were determined. Amendments of

90 electron acceptors and metabolism-specific inhibitors were added to identify and quantify the

91 role of different microbial communities for net $\mathrm{MeHg}$ formation in soil before and after forest

92 harvest.

94 MATERIALS AND METHODS

95 Site descriptions. Four mature (>80-years-old) Norway spruce (Picea abies Karst.)

96 reference stands (designated REFs) and four similar stands subjected to final harvest (clear-

97 cutting two years prior to the study, designated CCs) were selected. Two REFs and two CCs

98 were situated above the post-glacial marine limit (AML) of the ancient Baltic Sea, and two REFs

99 and two CCs were situated below the post-glacial marine limit (BML). All sites were located in

100 north-central Sweden and were part of a larger study ${ }^{22}$ including a total of 20 watersheds (Figure

$101 \mathrm{~S} 1$, Text S1). Sites represented an area of $26800 \mathrm{~km}^{2}$ covered by northern boreal coniferous

102 forests and corresponding to about 15\% of the forested land in Sweden. Sites situated AML were

103 located between 297 and 488 m.a.s.l. and sites BML between 16 and 113 m.a.s.l. To facilitate

104 comparison with parallel studies, the site designation follows Kronberg et al. ${ }^{22}$ 
106 CC3 situated the AML and sites REF1, REF4, CC2 and CC4 situated BML were selected for soil

107 sampling and determinations of $\mathrm{Hg}$ and $\mathrm{MeHg}$ soil pools. Site coordinates and topographic

108 characteristics are reported in Table S1, S2 (Supporting Information, SI). The organic (O)

109 horizon was collected in June 2011 (two years after clear-cutting) by cutting samples with a

110 specified volume from the side of dug pit with a steel knife. The O horizon was divided into the

111 top, non-humified Oe, and the underlying, humified Oa, horizon. The complete Oe horizon was

112 sampled and the top $15 \mathrm{~cm}$ of the Oa horizon. Depths of Oe and Oa and the underlying E horizon

113 and the level of the groundwater table (after $30 \mathrm{~min}$ to let the water stabilize) were measured in

114 the pit. In some pits large boulders prevented further digging and the groundwater level was set

$11510 \mathrm{~cm}$ below the maximum depth. Composite samples of Oe and Oa (comprised of five sub-

116 samples taken within a plot of 1 by $1 \mathrm{~m}^{2}$ ) were taken at five positions (P1-P5) along one hillslope

117 transect (in total $22-93 \mathrm{~m}$ long) running from recharge to discharge areas and positioned

118 perpendicular to the first-order stream defining the watershed. Sample P1 was taken $1 \mathrm{~m}$ from

119 the stream in the riparian zone and P5 in the recharge area. Samples P2-P4 were taken in

120 between at arbitrary distances from stream to cover local depressions at intermediate positions

121 along hillslopes. Billberry (Vaccinium myrtillus) was the dominant plant in the field layer at

122 REFs with Deschampsia flexuosa and other grasses and herbs gradually taking over after clear-

123 cutting. Feather mosses (Hylocomnium splendens, Pleurizium schreberi) dominated the bottom

124 layer at both REFs and CCs. Soils were classified as Podzols ${ }^{31}$ along hillslopes and Histosols (O

125 horizon $>40 \mathrm{~cm}$ ), with a patchy distribution, in the riparian zone along streams (having a width

126 of about 2-8 m). Sampling positions at REFs and CCs were selected to be as equal as possible in

127 relation to topography and average hydrology prior to clear-cutting. This was indeed achieved as 
128 judged by the thickness of the $\mathrm{O}$ horizon which proved to be very similar at REFs and CCs

129 (Figure 1, Table S5). Samples were stored in a cooling bag while transported to the lab and then

130 in a fridge at $4^{\circ} \mathrm{C}$. Within $48 \mathrm{~h}$ samples were homogenized through a $4 \mathrm{~mm}$ cutting sieve, after

131 removal of larger plant materials (roots) and woody debris. The soil was dried $\left(45^{\circ} \mathrm{C}\right.$ to avoid

132 losses of $\mathrm{Hg}$ ) and the fresh soil bulk density was calculated as gram of dry soil mass per $\mathrm{dm}^{-3}$.

133 Analytical methods for the determination of $\mathrm{Hg}_{\mathrm{TO}}, \mathrm{MeHg}$, and geochemical parameters $(\mathrm{pH}, \mathrm{C}$,

$134 \mathrm{~N}, \mathrm{~S}$ ) and water content are reported in Supporting Information (Text S2). Soil $\mathrm{MeHg}$ and $\mathrm{Hg}_{\text {TOT }}$

135 concentrations and areal masses were calculated for Oe and Oa horizons of REFs and CCs as

136 arithmetic means of the 20 composite samples (P1-P5 at four REFs and four CCs, respectively).

137 Data on $\mathrm{MeHg}$ and $\mathrm{Hg}_{\text {тот }}$ areal masses $\left(\mathrm{g} \mathrm{ha}^{-1}\right)$ for Oe and Oa sub-horizons were first summed

138 for each sampling position (P1-P5) before calculating the arithmetic average for the complete $\mathrm{O}$

139 horizon of REFs and CCs. Data on concentrations of $\mathrm{Hg}_{\mathrm{TO}}, \mathrm{MeHg}, \% \mathrm{MeHg}$, and water mass- $\%$

140 (of fresh soil) for Oe and Oa sub-horizons were weighted (by the measured sub-horizon

141 thickness) to calculate average values for the complete O horizons of CCs and REFs.

\section{Soil sampling and determination of potential $\mathrm{Hg}$ methylation and $\mathrm{MeHg}$}

143 demethylation rates. At four of the sites (REF1 AML, CC3 AML, REF4 BML, and CC4 BML)

144 soils were re-sampled in August 2012 (three years after clear-cutting) for incubation experiments

145 to determine $\mathrm{Hg}$ methylation and $\mathrm{MeHg}$ demethylation rate constants. Because no significant

146 differences in \% $\mathrm{MeHg}$ (of $\mathrm{Hg}_{\text {тот) }}$ ) were observed between Oe and Oa sub-horizons at the first

147 sampling occasion (in June 2011), the sampling in August 2012 was restricted to the top $10 \mathrm{~cm}$

148 of the $\mathrm{O}_{\mathrm{a}}$ horizon. At CCs, samples were taken at three of the five positions decided at the

149 sampling occasion in 2011: P1, P3 and P4 and at REFs samples were collected at two positions:

$150 \mathrm{P} 1$ and P4. Samples were taken using a soil corer with a steel edge (10.5 $\mathrm{cm}$ in diameter), 
151 immediately put in a ziplock plastic bag and kept in a cooling box on ice during transportation to 152 the lab. The samples were stored at $4^{\circ} \mathrm{C}$ in refrigerator for one week. Isotopically enriched ${ }^{198} \mathrm{Hg}\left(\mathrm{NO}_{3}\right)_{2},{ }^{201} \mathrm{Hg}-\mathrm{NOM}$ (natural organic matter), and $\mathrm{Me}^{204} \mathrm{HgCl}$

154 tracers were used in soil incubation experiments. The ${ }^{201} \mathrm{Hg}-\mathrm{NOM}$ tracer is less available for 155 methylation than the traditionally used ${ }^{198} \mathrm{Hg}\left(\mathrm{NO}_{3}\right)_{2}$ tracer, ${ }^{36}$ and can be assumed to be more 156 relevant as a substrate in an organic forest soil where the complexation of $\mathrm{Hg}(\mathrm{II})$ to $\mathrm{NOM}$ thiol 157 groups dominates the inorganic $\mathrm{Hg}$ speciation. ${ }^{37,38,54}$ The ${ }^{201} \mathrm{Hg}-\mathrm{NOM}$ tracer was prepared 5 days 158 prior to the incubation. ${ }^{36}$ Two days prior to the incubation, soil samples were homogenized by 159 hand in a plastic bag (to avoid soil water losses) in the glovebox $\left(95 \% \mathrm{~N}_{2}\right.$ and $\left.5 \% \mathrm{H}_{2}\right)$. This was 160 done as gently as possible, basically removing roots and mixing the sample by loosening up the 161 depth-related structures (layering) of the O horizon to provide a representative, mixed sample 162 still maintaining most of its small-scale structure. Subsamples were taken out for determination 163 of water content, total $\mathrm{Hg}\left(\mathrm{Hg}_{\mathrm{TOT}}\right)$ and $\mathrm{MeHg}$ concentrations (Text S2, SI). The latter two 164 analyzes were done immediately to decide the quantity of $\mathrm{Hg}$ and $\mathrm{MeHg}$ tracers to be added 165 (corresponding to $10-30 \%$ of ambient). Ten grams of homogenized soil were weighed (by two 166 decimals) into $50 \mathrm{~mL}$ Falcon tubes covered with aluminum foil. Amendments and isotopically 167 enriched tracers were added to the soil in a minimum amount of deoxygenated water (enough to 168 provide efficient mixing but still maintaining differences in water contents among soil samples).

169 The soil was mixed thoroughly using a metal spatula. A subsample $\left(\mathrm{t}_{48}\right)$ was transferred to a 170 second tube, weighed and incubated in darkness in the glovebox at $21 \pm 1^{\circ} \mathrm{C}$. After 48 hours the $171 \mathrm{t}_{48}$ sample was frozen at $-20^{\circ} \mathrm{C}$. The first tube $\left(\mathrm{t}_{0}\right)$ was frozen on dry ice after each amendment 172 was done, which took 10-15 minutes. All treatments were done in triplicate. Sulfate and freshly 173 prepared amorphous iron hydroxide ${ }^{39}$ (henceforth designated Fe(III)) were added as potential 
174 bacterial electron acceptors for SRB and IRB, respectively. Molybdate $\left(\mathrm{Na}_{2} \mathrm{MoO}_{4}\right)$ and

175 bromoethanesulfonic acid (BES) were added as specific inhibitors of SRB and methanogens, 176 respectively, ${ }^{40}$ and azide $\left(\mathrm{NaN}_{3}\right)$ was used as a general microbial metabolic inhibitor. ${ }^{41}$ Final 177 concentrations in the samples were $50 \mu \mathrm{M}$ of sulfate and molybdate, $10 \mathrm{mM}$ of BES, $1 \mathrm{~mol} / \mathrm{L}$ of 178 Fe(III), and $100 \mathrm{mM}$ azide. The CC4 P3 sample was excluded because of analytical problems. Potential methylation and demethylation rate constants $\left(\mathrm{d}^{-1}\right)$ were calculated by equations

180 (1) and (2), respectively, from masses of transformed ${ }^{201} \mathrm{Hg}\left({ }^{201} \mathrm{Hg}-\mathrm{NOM}\right.$ tracer $),{ }^{198} \mathrm{Hg}$

$181 \quad\left({ }^{198} \mathrm{Hg}\left(\mathrm{NO}_{3}\right)_{2}\right.$ tracer $)$ and $\mathrm{Me}^{204} \mathrm{Hg}\left(\mathrm{Me}^{204} \mathrm{HgCl}\right.$ tracer$)$. Because of the difficulty to directly

182 determine the pseudo-first order kinetics of $\mathrm{Hg}$ methylation $(\mathrm{dHg} / \mathrm{dt})$, and its dependency on the 183 quantity of added $\mathrm{Hg}$ tracer, $k_{m}$ in reaction (1) is commonly adopted as the potential methylation 184 rate constant. ${ }^{32}$ The demethylation rate constant is determined by pseudo first-order kinetics.

185 Demethylation of $\mathrm{Me}^{201,198} \mathrm{Hg}$ formed during the course of the incubation experiment, as well as 186 methylation of ${ }^{204} \mathrm{Hg}$, were assumed negligible.

$$
k_{m}=\left(\left[\mathrm{Me}^{201,198} \mathrm{Hg}\right] t_{48}-\left[\mathrm{Me}^{201,198} \mathrm{Hg}\right] t_{0}\right) /\left(\left[{ }^{201,198} \mathrm{Hg} \text {-tracer }\right]_{\text {added }} \times \Delta t\right)
$$

$$
k_{d}=-1 \times\left(\ln \left[\mathrm{Me}^{204} \mathrm{Hg}\right] t_{48}-\ln \left[\mathrm{Me}^{204} \mathrm{Hg}\right] t_{0}\right) / \Delta \mathrm{t}
$$

189 The $[\mathrm{MeHg}] \mathrm{t}_{48}$ and $[\mathrm{MeHg}] \mathrm{t}_{0}$ are the determined $\mathrm{MeHg}$ concentrations $\left(\mathrm{ng} \mathrm{Hg} \mathrm{g}^{-1}\right)$ for a given 190 isotope at 48 hours $\left(\mathrm{t}_{48}\right)$ and at the start of the experiment $\left(\mathrm{t}_{0}\right)$. The $\left[{ }^{201,198} \mathrm{Hg} \text {-tracer }\right]_{\text {added }}$ is the 191 initial concentration of isotope tracer and $\Delta \mathrm{t}$ is the incubation time (days).

Two-tailed Student's $t$-test for heteroscedastic distributed log-transformed data were used 193 to compare soil data for REFs and CCs. Differences between controls and treatments of 194 incubation studies were tested by ANOVA followed by Tukey multiple comparison test. 
Soil concentrations and areal masses of Нgтот and MeHg along hillslopes. As previously reported, ${ }^{22}$ average $\mathrm{O}$ horizon $\mathrm{Hg}_{\text {Tот }}$ concentrations and $\mathrm{Hg}_{\text {TOт }}$ areal masses did not differ between the REF (210 $\mathrm{ng} \mathrm{g}^{-1}$ and $41 \mathrm{~g} \mathrm{ha}^{-1}$, respectively) and CC sites (220 $\mathrm{ng} \mathrm{g}^{-1}$ and $48 \mathrm{~g} \mathrm{ha}^{-1}$, respectively) of this study. In contrast, $\mathrm{MeHg}$ concentrations $(\mathrm{p}=0.002)$ and areal masses of $\mathrm{MeHg}(\mathrm{p}=0.006)$ and $\mathrm{MeHg}$ in $\%$ of $\mathrm{Hg}_{\text {тот }}(\mathrm{p}=0.003)$ were significantly higher at $\mathrm{CC}\left(4.8 \mathrm{ng} \mathrm{g}^{-1}\right.$, $1.1 \mathrm{~g} \mathrm{ha}^{-1}$, and $2.7 \%$, respectively) than at REF sites $\left(1.0 \mathrm{ng} \mathrm{g}^{-1}, 0.16 \mathrm{~g} \mathrm{ha}^{-1}\right.$, and $0.4 \%$, respectively). Similar differences between REFs and CCs were reported for the sub-horizons Oe and $\mathrm{Oa}$ (Figure S2, SI). In summary, concentrations and areal masses of MeHg in CCs were 9-12

204 times and 4-7 times higher that REFs in the Oe and Oa horizons, respectively, and 5-7 times 205 higher than REFs in the O horizon as a whole. Individual data for all sampling sites are reported 206 in the Supporting Information (Table S3, S4, SI).

The average thickness and bulk density of the O horizon was similar at REF $(29 \pm 22 \mathrm{~cm}$ 208 and $\left.64 \pm 19 \mathrm{~g} \mathrm{dm}^{-3}\right)$ and CC $\left(29 \pm 13 \mathrm{~cm}\right.$ and $69 \pm 32 \mathrm{~g} \mathrm{dm}^{-3}$, Table S5, SI $)$ sites. At sampling 209 positions P1-P4 (situated $1-38 \mathrm{~m}$ from stream) the average O horizon thickness varied between 21026 and $32 \mathrm{~cm}$ at both REFs and CCs (Figure 1). Even if the thickness did not meet criteria for 211 peat formation (Histosols: $>40 \mathrm{~cm}$ organic horizon) it is indicative of an average groundwater 212 table close enough to the surface to periodically saturate most of the $\mathrm{O}$ horizon. Further away, at 213 sampling point P5, well-drained Podzols with typical O horizons (REF: $10 \mathrm{~cm}, \mathrm{CC}: 13 \mathrm{~cm}$ ) were 214 developed. At the sampling occasion in June, in the middle of a dry spell, the groundwater at 215 CCs reached into the lower part of the Oa horizons, while at REFs the level was several dm 216 deeper (Figure 1, Table S5, SI). 

In parallel to the groundwater level, the water content of the $\mathrm{O}$ horizon was enhanced at

218 CCs and reached a maximum at some distance from the stream. Water contents were

219 significantly higher at CCs as compared to REFs at sampling locations P3 ( $\mathrm{p}=0.03$ ) and P4

$220(p=0.055$, Figure 1, Table S6, SI). At REFs there was no clear pattern for the soil water content

221 with distance to stream. The soil organic carbon content was significantly higher at REFs,

222 indicative of soil disturbance and mineral matter mixing into the O horizon after clear-cutting.

223 One meter from stream (P1) MeHg expressed as concentrations, areal masses and \% of

$224 \mathrm{Hg}_{\text {тот }}$ were all significantly higher at CCs than at REFs (Figure 1, Table 1 and S6). A significant

225 enhancement at CCs were also observed at position P3 (for MeHg concentrations and \% of

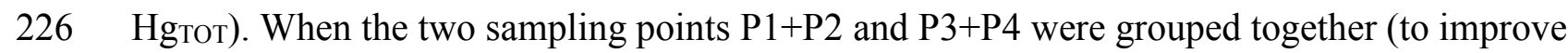

227 statistical testing) the enhancement of $\mathrm{MeHg}$ at CCs (in relation to REFs) was most pronounced

228 at intermediate positions (P3+P4) along hillslopes. MeHg concentrations were enhanced seven

229 times $(\mathrm{p}=0.009)$ at $\mathrm{P} 3+\mathrm{P} 4$ and four times at $\mathrm{P} 1+\mathrm{P} 2(\mathrm{p}<0.04)$ and $\% \mathrm{MeHg}$ was enhanced 12 times

$230(\mathrm{p}=0.003)$ at $\mathrm{P} 3+\mathrm{P} 4($ Table S6). Soil water contents were significantly enhanced at CCs at P3

$231(\mathrm{p}=0.003)$ and $\mathrm{P} 3+\mathrm{P} 4(\mathrm{p}=0.0003)$. Further up along the hillslope, moving into the recharge area

232 (at P5), groundwater levels, soil water contents and $\mathrm{MeHg}$ measures (Figure1) all reached the

233 lowest values along transects and differences between CCs and REFs were not significant.

234 Concentrations and areal masses of $\mathrm{Hg}_{\text {TOT }}$ generally decreased by distance from the stream

235 (Figure 1, Table 1 and S5) and showed no significant differences between REFs and CCs. Both

$236 \mathrm{C} / \mathrm{N}$ and $\mathrm{C} / \mathrm{S}$ ratios $(\mathrm{g} / \mathrm{g})$ in the $\mathrm{O}$ horizon remained very similar: $28 \pm 10$ and $240 \pm 72$,

237 respectively, at CCs, $30 \pm 9.4$ and $240 \pm 59$, respectively, at REFs. 

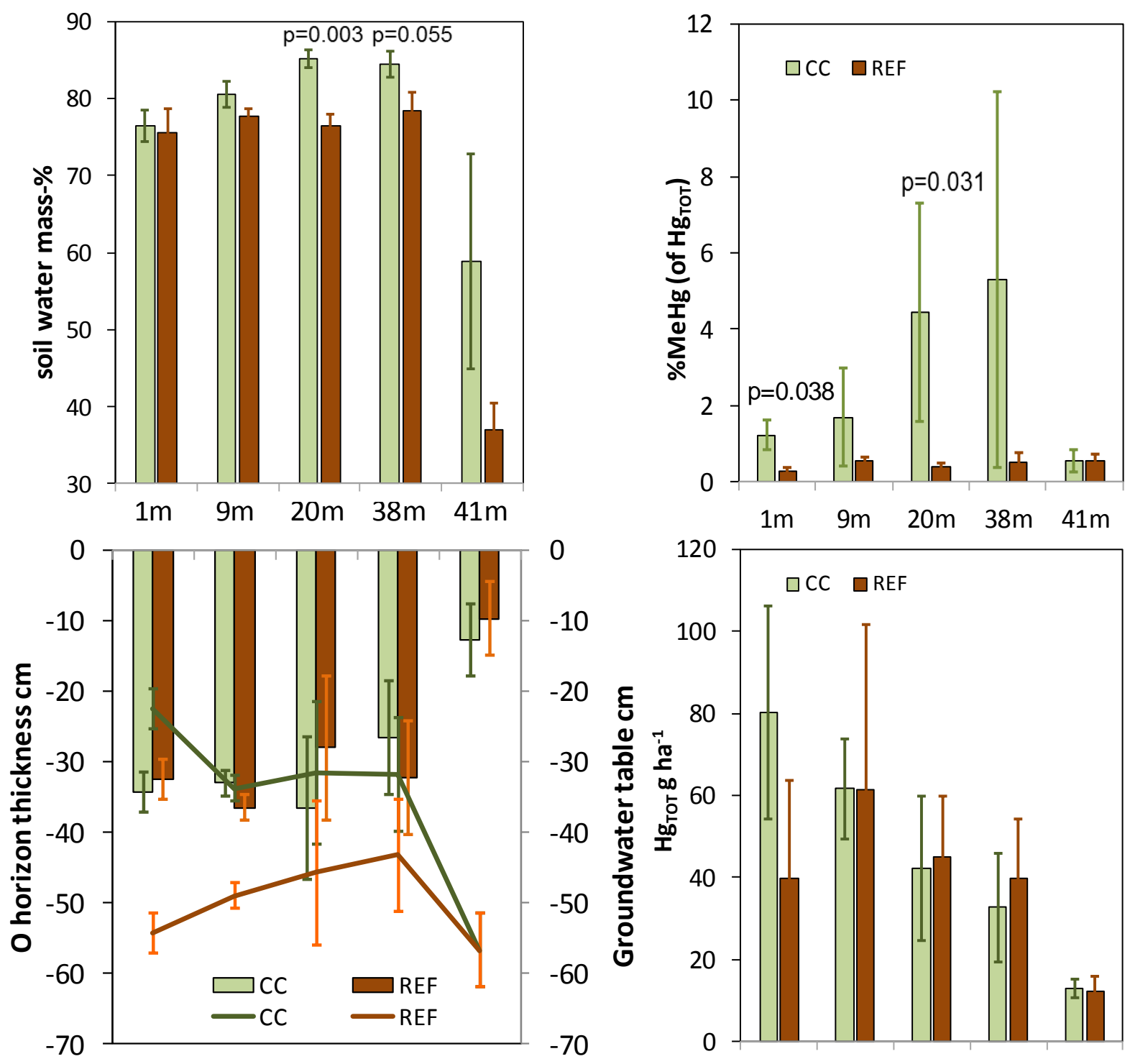

239 Figure 1. Spatial pattern of mass-\% soil water (upper left), O horizon thickness (bars) and

240 groundwater table (lines, lower left) and \% $\mathrm{MeHg}$ of $\mathrm{Hg}_{\mathrm{TOT}}$ and areal mass of $\mathrm{Hg}_{\mathrm{TOT}}$ (right) for

241 the five sampling points (P1-P5) along hillslopes with average distances to stream denoted.

242 Average values $\pm \mathrm{SE}$ are reported for reference stands $(\mathrm{REF}, \mathrm{N}=4)$ and clear-cuts $(\mathrm{CC}, \mathrm{N}=4)$.

243 Data are reported in Table S5 and S6, SI. All sampling positions were forested at REFs and prior 244 to harvest at CCs. 
245 Table 1. Average $( \pm \mathrm{SD})$ O horizon concentrations of total mercury $\left(\mathrm{Hg}_{\mathrm{TOT}}\right)$ and methyl mercury

246 (MeHg) and areal masses of $\mathrm{MeHg}$ for composite soil samples taken at five hillslope positions

247 (P1-P5) at four sites. Figures in bold italics denote significant differences between references

248 (REF) and clear-cuts (CC). Data on \% MeHg, areal masses of $\mathrm{Hg}_{\text {TOт }}\left(\mathrm{g} \mathrm{ha}^{-1}\right)$ and soil water and

249 soil organic carbon mass-\% are reported in Table S6, SI.

\begin{tabular}{|c|c|c|c|c|c|c|}
\hline \multirow[t]{2}{*}{$\begin{array}{l}\text { Hillslope } \\
\text { position }\end{array}$} & \multicolumn{2}{|c|}{$\begin{array}{l}\mathrm{Hg}_{\text {тот }} \\
\left(\mathrm{ng} \mathrm{g}^{-1}\right)\end{array}$} & \multicolumn{2}{|c|}{$\begin{array}{l}\mathrm{MeHg} \\
\left(\mathrm{ng} \mathrm{g}^{-1}\right)\end{array}$} & \multicolumn{2}{|c|}{$\begin{array}{l}\mathrm{MeHg} \\
\left(\mathrm{g} \mathrm{ha}^{-1}\right)\end{array}$} \\
\hline & REF & $\mathbf{C C}$ & REF & $\mathbf{C C}$ & REF & CC251 \\
\hline $\mathrm{P} 1 \mathrm{~m}(\mathrm{~N}=4)$ & $170 \pm 53$ & $210 \pm 95$ & $0.6 \pm 0.4^{a}$ & $2.8 \pm 1.1^{b}$ & $0.16 \pm 0.20^{a}$ & $1.1 \pm 0.5^{b}$ \\
\hline $\mathrm{P} 29 \mathrm{~m}(\mathrm{~N}=4)$ & $220 \pm 59$ & $250 \pm 17$ & $1.3 \pm 0.5$ & $4.0 \pm 5.8$ & $0.26 \pm 0.14$ & $0.94 \pm 1.2$ \\
\hline P3 20m (N=4) & $220 \pm 35$ & $190 \pm 46$ & $0.8 \pm 0.6^{a}$ & $7.2 \pm 6.5^{b}$ & $0.13 \pm 0.09$ & $2.0 \pm 2.4$ \\
\hline $\mathrm{P} 438 \mathrm{~m}(\mathrm{~N}=4)$ & $220 \pm 21$ & $200 \pm 35$ & $1.3 \pm 1.1$ & $7.9 \pm 6.0$ & $0.20 \pm 0.13$ & $1.2 \pm 1.1$ \\
\hline P5 41m (N=3) & $190 \pm 10$ & $230 \pm 54$ & $1.0 \pm 0.6$ & $1.2 \pm 1.2$ & $0.05 \pm 0.03$ & $0.06 \pm 0.04$ \\
\hline $\mathrm{P} 1+\mathrm{P} 2(\mathrm{~N}=8)$ & $200 \pm 22$ & $230 \pm 25$ & $0.9 \pm 0.2^{a}$ & $3.4 \pm 1.5^{b}$ & $0.21 \pm 0.06^{a}$ & $1.1 \pm 0.3^{b}$ \\
\hline $\mathrm{P} 3+\mathrm{P} 4(\mathrm{~N}=8)$ & $220 \pm 10$ & $195 \pm 14$ & $1.1 \pm 0.3^{a}$ & $7.6 \pm 2.2^{b}$ & $0.16 \pm 0.04^{c}$ & $1.6 \pm 0.7^{d}$ \\
\hline $\mathrm{P} 1$ to $\mathrm{P} 5(\mathrm{~N}=20)$ & $210 \pm 43$ & $220 \pm 54$ & $1.0 \pm 0.7^{a}$ & $4.8 \pm 5.1^{b}$ & $0.16 \pm 0.14^{a}$ & $1.1 \pm 1.4^{b}$ \\
\hline
\end{tabular}

252

Methylation and demethylation incubation studies. Rate constants for the potential

254 methylation and demethylation, $k_{m}$ and $k_{d}$, were determined in incubation experiments of soil Oa 255 horizon samples collected in August 2012, three years after final harvest. The water content of 256 soil samples taken in August 2012 (68-91\%, Table S7,SI) were similar to samples taken in June 2572011 (65-86\%, Table S6, SI). Also similar to in June 2011, clear-cuts (CC3, CC4) demonstrated 258 higher \% $\% \mathrm{MeHg}$ and higher water contents in positions P3 and P4 than in position P1 (Table S7, 259 SI). Soil samples at the reference stands (REF1 P1 \& P3, REF4 P1) all showed lower water 260 contents and substantially lower concentrations of $\mathrm{MeHg}$ (and $\% \mathrm{MeHg}$ of $\mathrm{Hg}_{\text {Tот }}$ ) than all the $\mathrm{CC}$ 261 samples. Notable was the high concentration of $\mathrm{MeHg}$ (and \% $\mathrm{MeHg}$ ) and water content at 
262 sample point P3 in REF4. This sample was affected by clear-cutting of the forest stand further up

263 along the slope just a short distance from the sampling point, conducted one year before the

264 sampling occasion. The clear-cutting effect noted for $\mathrm{MeHg} \%$ at REF4 P3 was also reflected by

265 the potential methylation rate constant $k_{m}\left(0.029 \mathrm{~d}^{-1}\right)$, which fell into the range observed for the

266 six CCs $\left(0.014-0.582 \mathrm{~d}^{-1}\right)$. In contrast, the three true REFs showed much lower methylation rate

267 constants $\left(0.0001-0.007 \mathrm{~d}^{-1}\right.$, Table S7, SI). Statistical testing conducted with REF4 P3 considered

268 to be affected by clear-cutting (and thus included as a CC) revealed that CC soils (N=7) had

269 significantly higher concentrations of $\mathrm{MeHg}(p=0.003), \% \mathrm{MeHg}(p=0.010), k_{m}(p=0.048$, one-

270 tailed test) and water content $(p=0.017)$ than REFs $(\mathrm{N}=3)$, Figure 2. Potential demethylation rate

271 constants showed no response to clear-cutting, as illustrated by similar ranges for CCs (0.006-

272 0.081) and REFs (0.005-0.173), Table S7, SI.
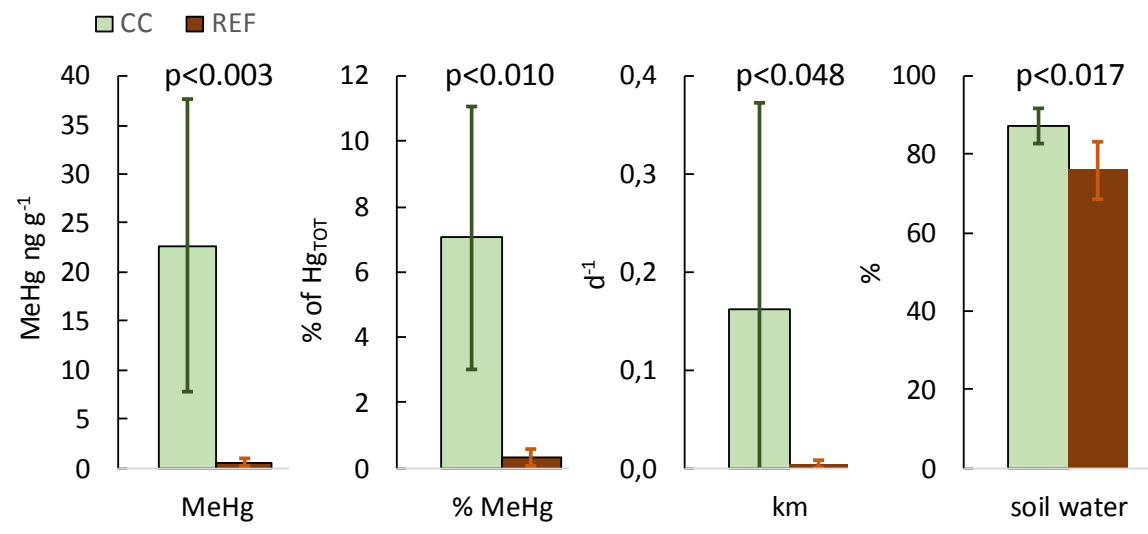

273 Figure 2. Average $( \pm \mathrm{SD})$ concentrations of $\mathrm{MeHg}, \% \mathrm{MeHg}$ of $\mathrm{Hg}_{\mathrm{TOT}}$ in soil prior to incubation,

274 potential methylation rate constant $\left(k_{m}\right)$ and soil water content ( $\%$ of wet soil mass) for soil

275 samples taken at clear-cuts (CCs, including REF4 P3 that was affected by clear-cutting, N=7)

276 and reference stands (REFs, N=3). Data in Table S7, SI. Corresponding plots for log-transformed

277 data are for clarity presented in SI, Figure S3. 
278 Amendments of electron acceptors and inhibitors. In three of the five CC soils, and in the

279 REF4 BML P3 soil (which was affected by clear-cutting), there was a significant $(\mathrm{p}<0.05)$

280 increase in $k_{m}$ after addition of the potential electron acceptor sulfate (Figure 3). In two of these

281 samples also addition of the electron acceptor Fe(III) enhanced $k_{m}$ : one significantly $(\mathrm{p}<0.05$;

282 CC4 BML P3) and one almost significantly ( $p<0.10$; REF4 BML P3). None of the REF samples

283 were significantly affected by additions of sulfate and Fe(III).

The microbial inhibitor azide significantly $(p<0.05)$ or almost significantly $(p<0.10)$

285 decreased the $k_{m}$ in all CC samples (including REF4 BML P3) and in two out of three REFs.

286 Amendment with BES (specific inhibitor for methanogens) significantly $(p<0.05)$ reduced $k_{m}$ by

287 almost half in four of the six CC samples (CC4 BML P1, P3 and P4, and CC3 AML P3). A

288 significant decrease was also observed in REF1 AML P1. Further, in response to addition of the

289 specific inhibitor of SRB (molybdate), $k_{m}$ decreased significantly $(p<0.05)$ in the CC4 BML P1

290 sample and almost significantly in the CC4 BML P4 sample $(p=0.06)$.

The effect of isotope labeled inorganic $\mathrm{Hg}$ tracers with different availability for

292 methylation was evaluated by comparing the relative differences in $k_{m}$ determined from the

$293{ }^{198} \mathrm{Hg}\left(\mathrm{NO}_{3}\right)_{2}$ and ${ }^{201} \mathrm{Hg}-\mathrm{NOM}$ tracers. For the $\mathrm{Hg}\left(\mathrm{NO}_{3}\right)_{2}$ tracer, rate constants were about 20

294 times higher than for the Hg-NOM tracer (Figure S4), well in agreement with previous

295 findings. ${ }^{36}$ As noted from the figure the pattern of relative response to electron acceptor and 296 inhibitor amendments was similar for the ${ }^{198} \mathrm{Hg}\left(\mathrm{NO}_{3}\right)_{2}$ and ${ }^{201} \mathrm{Hg}-\mathrm{NOM}$ tracers.

298 effect on demethylation rates (Figure S5). 

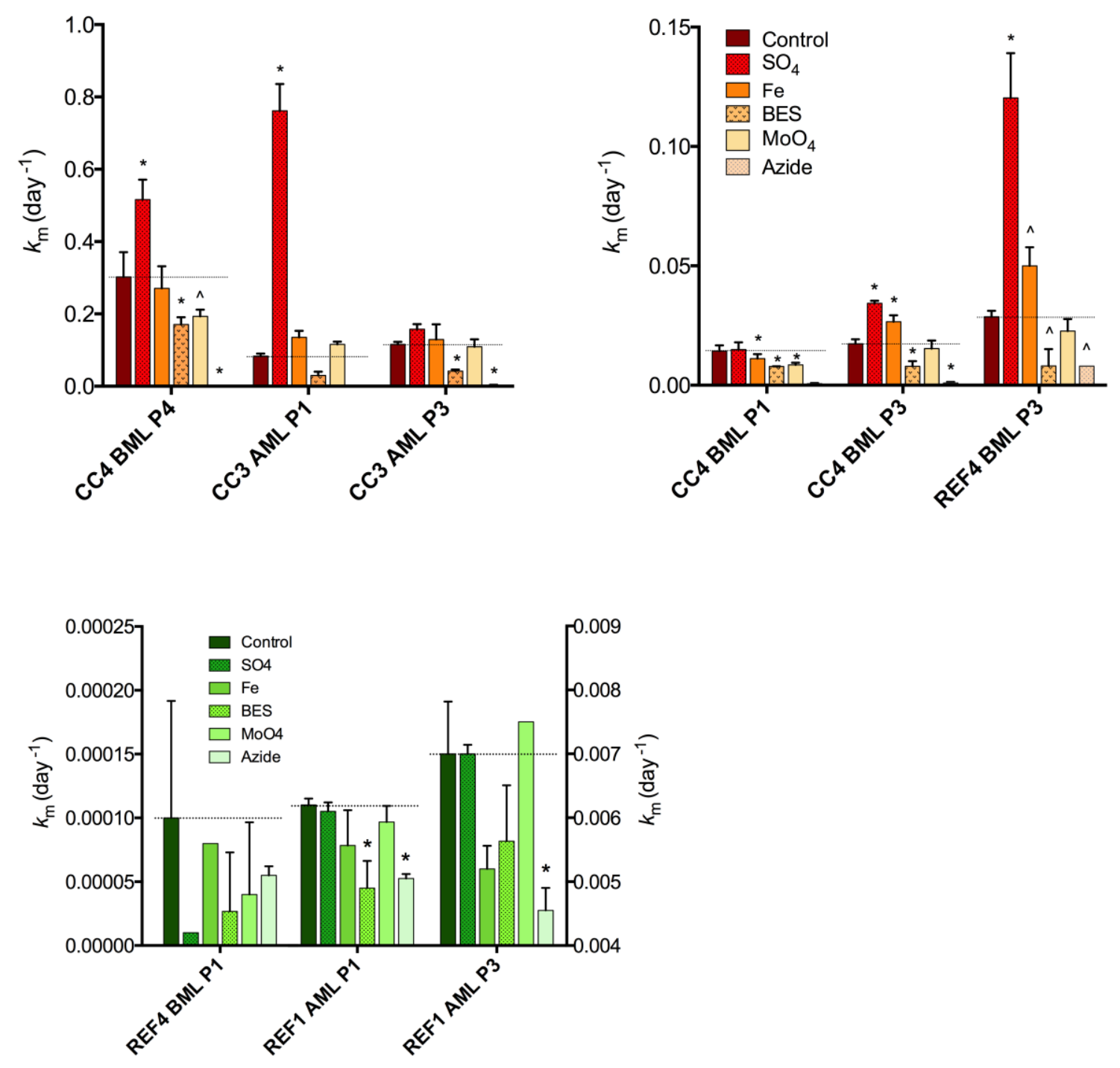

Figure 3. Potential methylation rate constants $\left(k_{m}\right)$ determined for the ${ }^{198} \mathrm{Hg}\left(\mathrm{NO}_{3}\right)_{2}$ tracer.

301 Control samples are compared with samples amended with electron acceptors (sulfate, Fe(III))

302 and microbial inhibitors (BES, molybdate, azide). The asterisk $(*)$ denotes significant differences

$303(\mathrm{p}<0.05$, ANOVA + Tukey multiple comparison test $)$ and $\left({ }^{\wedge}\right)$ marginally non-significant

304 differences $(\mathrm{p}<0.07)$ from control (horizontal dotted lines). Error bars represent the standard

305 deviation for triplicates. In the lower figure REF1 AML P1 and P3 are plotted on the right axis. 
308 Previous studies of boreal forest harvest have demonstrated increased $\mathrm{MeHg}$ concentrations in

309 stream runoff and in downstream biota, ${ }^{16-22}$ but the source of $\mathrm{MeHg}$ has not been clearly

310 identified. Here we extend the findings from Kronberg et al., ${ }^{22}$ demonstrating increased $\mathrm{MeHg}$

311 pools in the $\mathrm{O}$ horizon after clear-cut, by reporting spatial distributions along recharge-discharge

312 transects. Spatially, $\mathrm{MeHg}$ soil quantities were most enhanced at some distance from the stream,

313 well outside the riparian zone, where also the water content of the O horizon was significantly

314 enhanced (Figure 1). Thus, the most important factor for creating oxygen deficiency in soil:

315 water saturation, likely played an important role to enhance soil MeHg after forest clear-cutting.

As a consequence of forest harvest, evapotranspiration significantly decreases ${ }^{25}$ and the

317 runoff was shown to be enhanced on average $62 \%$ at the CC sites above the ML of this study. ${ }^{22}$

318 The extra water supply will extend the discharge area from the riparian zone patches of Histosols

319 into better drained O horizons of Podzols in lower sections and local depressions of hillslopes.

320 The water table positioned in the lower part of the Oa horizon at CCs (Figure 1) demonstrates the

321 effect of increased water supply after final harvest. Even if the O horizon in average was as thick

322 as $26-36 \mathrm{~cm}$ at sampling positions P2-P4 (located in average 9 to $38 \mathrm{~m}$ from streams), the

323 development of E and Bhs and Bs horizons (diagnostic for Podzols) prove at least seasonally

324 relatively well-drained conditions prior to clear-cutting. It has been demonstrated that

325 experimental flooding of well-drained upland soil $\mathrm{O}$ horizons results in high rates of $\mathrm{Hg}$

326 methylation and $\mathrm{MeHg}$ accumulation in soils. ${ }^{28,44}$ This observation has primarily been explained

327 by a higher availability of electron donors (for methylating microbes) in relatively well-drained

328 Podzol O horizons, as compared to the more recalcitrant organic matter accumulated in

329 Histosols. ${ }^{28,44,53}$ We therefore suggest that hot-spots for MeHg net formation after forest clear- 
330 cutting are mainly to be found in lower sections (including local depressions) of hillslopes, at

331 some distance from streams, where the combination of high availability of electron donors and

332 increasing groundwater tables stimulates the activity of anaerobic microbes..

This picture also agrees well with our previous findings that stream $\mathrm{MeHg}$

334 concentrations $^{20}$ and annual $\mathrm{MeHg}$ export $^{22}$ is most clearly enhanced after forest harvest in

335 undulating terrain with small riparian zones, as compared to flatter landscapes with a larger

336 contribution from riparian zones and wetlands. The more or less continuous layer of organic soil,

337 connecting near stream Histosols with O horizons of Podzols in lower sections of hillslopes,

338 possess a high hydraulic conductivity and serves as permeable medium for lateral movement of

339 water and its solutes from soils to streams under high-flow conditions. ${ }^{43}$ Thus, through this

340 medium, $\mathrm{MeHg}$ bonded to mobile organic matter ${ }^{45}$ will readily be transported from the hot-spots

341 of $\mathrm{MeHg}$ formation in soil to the stream.

Soil samples taken at positions along hillslopes, which were demonstrating significantly

343 enhanced concentrations and areal masses of MeHg two years (Table 1, Table S6) and three

344 years (Table S7) after clear-cutting, also showed significantly enhanced methylation rate

345 constants $\left(k_{m}\right)$, as compared to REFs (Figure 2). Thus, a positive relationship was observed

346 between $\% \mathrm{MeHg}$ (of $\mathrm{Hg}_{\text {TOт }}$ ) in soils and $k_{m}$ determined in the same soil after short-term (48 h)

347 incubation (Figure 4). Similar relationships have been reported for sediments. ${ }^{51}$ Because the $k_{m}$ is

348 a true measure of short-term $\mathrm{MeHg}$ formation, the relationship can been seen as a confirmation

349 that the build-up of \% MeHg in soils (2-3 years) after forest harvest indeed is due to an increased

350 net formation of $\mathrm{MeHg}$. Because demethylation rate constants $\left(k_{d}\right)$ overlapped largely between

351 CCs and REFs (Figure S4) it is concluded that the increased O horizon pool of MeHg after final 
352 harvest is mainly caused by an enhanced rate of methylation and not by a decreased rate of 353 demethylation.

\section{a}

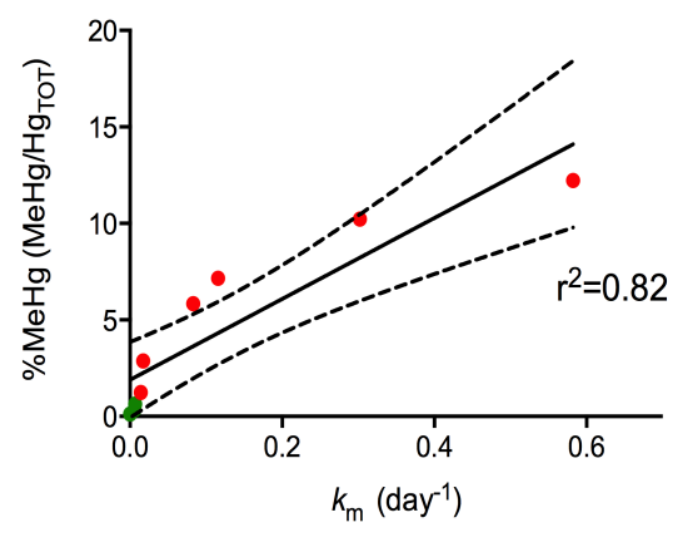

b

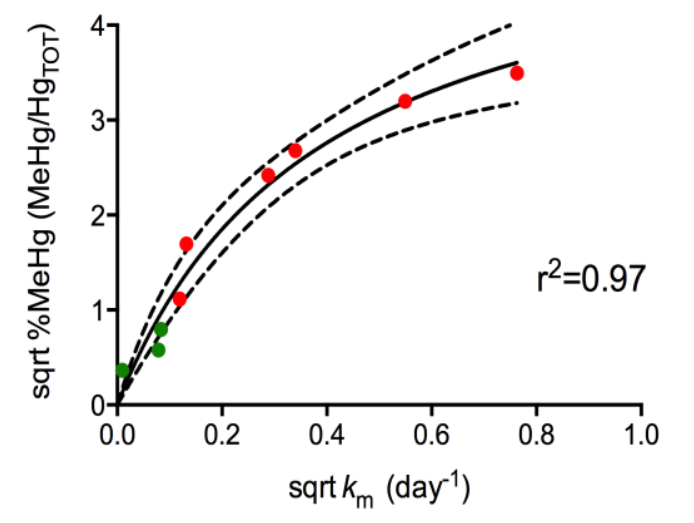

- CCs

- REFs

356 Figure 4. Relationships between \% $\mathrm{MeHg}$ (of $\mathrm{Hg}_{\text {TOT) }}$ ) in soil samples prior to incubation and

357 potential $\mathrm{Hg}$ methylation rate constant $k_{m}$ determined for clear-cuts (CCs, red symbols $\left.\mathrm{N}=6\right)$ and

358 references (REFs, green symbols $\mathrm{N}=3$ ). Linear model (a) and nonlinear model (b). The sample

359 REF4 BML P3 was excluded from the plot. Dotted lines display 95\% confidence intervals.

361 It is reasonable to argue that factors in control of the longer-term build-up of $\mathrm{MeHg}$ in soils after

362 clear-cutting also were largely responsible for the high methylation rate (as compared to REFs)

363 as determined in the $48 \mathrm{~h}$ laboratory experiments. The considerable thickness of the sampled $\mathrm{O}$

364 horizons of both REFs and CCs (29 $\mathrm{cm}$ in average) suggest they were regularly affected by water

365 saturation during periods of high flow events such as spring snowmelt and autumn rains, at least

366 during the last rotation period of the forest stand. As a consequence of forest harvest, the 
367 groundwater table at CCs was further increased and reached into the lower part of the O horizon

368 even during a very dry period of the year (Figure 1). Thus it is expected that water saturated

369 conditions prevailed throughout most of the year at sampling positions P1-P4 at CC sites. This

370 study did not include genetic or molecular work to quantify abundance of different groups of

371 bacteria, but given the hydrologic conditions after forest harvest, it is expected that an active

372 community of anaerobic microbes were built-up in the water-saturated $\mathrm{O}$ horizon soils after

373 forest harvest.

In addition to microbial activity, the chemical speciation of $\mathrm{Hg}$ and $\mathrm{MeHg}$ is expected to

375 influence the absolute rates at which these forms transform in the soil. ${ }^{56}$ Soil porewater chemistry

376 was not characterized in this study, but streams draining REFs and CCs generally showed a

377 dominance of $\mathrm{Fe}(\mathrm{II})$ over Fe(III) and sulfide was (barely) detected $(>0.3 \mu \mathrm{M})$ in a few streams. ${ }^{22}$

378 A comparison of $\mathrm{C} / \mathrm{N}$ and $\mathrm{C} / \mathrm{S}$ ratios in soils reveal no differences between REFs and CCs.

379 Because sulfide readily reacts and becomes incorporated into NOM in permanent sulfate

380 reducing environments, ${ }^{47,48}$ the $\mathrm{C} / \mathrm{S}$ ratio provide a time-integrated measure of sulfate reduction

381 in organic soils. The production of sulfide was obviously not large enough to significantly

382 decrease the $\mathrm{C} / \mathrm{S}$ ratio in soils of CCs below the values of the REFs (Table S5, SI).

In the $\mathrm{O}$ horizon soils of this study both $\mathrm{Hg}$ and $\mathrm{MeHg}$ are expected to be almost

384 exclusively complexed by NOM associated thiol groups (RSH). ${ }^{37,38,47,54,57}$ Spectroscopic studies

385 of NOM from O horizon soils of Podzols and Histosols and dissolved OM in streams in the

386 region suggest that the concentration of RSH group make up on average 0.15 mass- $\%$ of organic

$387 \mathrm{C}^{54,55}$. Based on \% soil organic C (Table S6, SI) and soil pH $(3.8( \pm 0.3)$ in REFs and $4.2( \pm 0.2)$

388 in CCs) in the soils, and an maximum concentration of dissolved inorganic sulfides of 1-2 $\mu \mathrm{M}$ in

389 soil porewater, even in the most anoxic riparian soils of the study area, ${ }^{7,57}$ thermodynamic 
390 calculations demonstrate that $\mathrm{Hg}(\mathrm{SR}-\mathrm{NOM})_{2}$ and MeHgSR-NOM complexes will constitute 391 more than $95 \%$ of $\mathrm{Hg}$ and $\mathrm{MeHg}$, respectively, in the soils of this study. ${ }^{55}$

Given the dominance of $\mathrm{Hg}(\mathrm{SR}-\mathrm{NOM})_{2}$ complexes in the soils, we expect the ${ }^{201} \mathrm{Hg}$ -

393 NOM tracer to reflect the availability for methylating bacteria better than the ${ }^{198} \mathrm{Hg}\left(\mathrm{NO}_{3}\right)_{2}$ tracer.

394 However, since the chemical speciation of $\mathrm{Hg}$ (and $\mathrm{MeHg}$ ) at ambient conditions in soils cannot

395 be reliably simulated by any isotopic enriched tracer, there is currently no method available for

396 accurate determination of actual $\mathrm{Hg}$ methylation or $\mathrm{MeHg}$ demethylation rates in soil. Therefore

397 the relevance of the results of is study (and other incubation studies conducted in laboratory

398 systems) relies on the clear demonstration that incubation of $\mathrm{Hg}-\mathrm{NOM}$ and $\mathrm{Hg}\left(\mathrm{NO}_{3}\right)_{2}$ tracers in

399 estuarine sediments at both micro $^{36}$ and mesocosm ${ }^{50}$ scales, as well as in a wide range of wetland

400 soils, ${ }^{57}$ give very similar results on a relative scale when soils or sediments are compared. Thus

401 the Hg-tracer method is highly relevant for comparative purposes. The results further suggest

402 that other factors than the $\mathrm{Hg}$ speciation are in control of the large differences observed between

403 REFs and CCs when regards to $\mathrm{MeHg}$ build-up in soils and $k_{m}$ determined in laboratory

404 experiments. In addition to the microbial activity, electron donors and acceptors need to be

405 considered.

Potential electron acceptors (Mn (IV), $\mathrm{Fe}(\mathrm{III}), \mathrm{SO}_{4}{ }^{2-}$ ) and electron-donors (low molecular

407 mass organic compounds and $\mathrm{H}_{2}$ ) for anaerobic microbes were not determined in the soils, but

408 amendments of electron acceptors and inhibitors during the incubation experiments can provide

409 useful information on these aspects, as well as on the activity and identity of bacteria responsible

410 for the methylation of $\mathrm{Hg}$. By necessity additions of redox modulating constituents like Mn(IV),

$411 \mathrm{Fe}(\mathrm{III})$ and $\mathrm{SO}_{4}{ }^{2-}$ will affect the redox conditions in the incubation slurries. A caveat may be in

412 place, since it cannot be ruled out that the amendments may be differently affected in different 
413 soil samples, due to some variation in the composition of soil constituents and chemistry. That

414 being said, it should be noted that the soils in this study can be expected to represent a narrow

415 collection of biogeochemical conditions. As reflected by uniform \% organic $\mathrm{C}, \mathrm{C} / \mathrm{N}$ and $\mathrm{C} / \mathrm{S}$

416 ratios, and the small contribution from reactive mineral components, we do expect the abiotic

417 soil components to module the effect of amendments in a much similar way in all samples. Thus

418 effects of amendments should be reliable, as reflected by the small errors of replicates which

419 provided significances although the data material was not very extensive.

420 The effect of the azide amendment demonstrated that Hg methylation was a biotic

421 process. SRB were indicated to be present in most CC soils as indicated by the stimulatory effect

422 of sulfate and inhibitory effect of molybdate (Figure 3). The effect of sulfate suggests this

423 electron acceptor may have limited the $\mathrm{Hg}$ methylating bacteria in CC soils. In contrast, sulfate

424 had no effect in any of the REFs and molybdate had an effect only in one REF. This may suggest

425 that the population of SRB was not very large, or at least not very active in the REF soils. The

426 inhibitory effect of BES in all CCs further points at methanogens contributing to $\mathrm{MeHg}$

427 formation after clear-cut. BES only had an effect in one of the REFs, again implying that either

428 the activity and/or the population size of methanogens were small in REF soils. Notably, in two

429 of the clear-cut samples (CC4 BML P1 and P4) the significant inhibitory effects of BES and

$430 \mathrm{MoO}_{4}$ were similar in size. This may indicate a syntrophic relationship between the SRB and

431 methanogenic communities, and that this interaction was stimulated after forest harvest.

Given that the combined inhibition of SRB by molybdate and inhibition of methanogens

433 by BES only halved the methylation rate constant, as compared to the control, it is reasonable

434 that IRB and/or firmicutes ${ }^{13,14}$ also may have contributed to the increased $\mathrm{Hg}$ methylation after

435 clear-cut. The fact that Fe(III) hydroxide addition did not result in significant responses (with the 
436 exception of one CC sample), suggests that if IRB were present they were not limited by electron 437 acceptors. Molybdate amendment proved SRB being responsible for the majority (up to 95\%) of $438 \mathrm{MeHg}$ formation in riparian zone wetlands from the same boreal landscape as in this study. ${ }^{7}$ In 439 this study the role of methanogens was not tested. A stimulatory effect by sulfate addition has 440 been demonstrated in wetland soils in northern forest ecosystems, ${ }^{49}$ but not before in forest soils. In addition to quantifying soil pools of $\mathrm{MeHg}$, this is the first study reporting potential 442 methylation and demethylation rate constants, including effects of electron acceptor and donor 443 amendments, related to forest harvest. In lack of process-oriented studies on $\mathrm{Hg}$ biogeochemistry 444 after forest harvest, it may prove relevant to compare our results with studies of wetland soils in 445 the same type of boreal landscape (and using the same incubation method). The range of $446 \% \mathrm{MeHg}$ reported for CCs $\left(0.2-11.8 \%\right.$ of $\mathrm{Hg}_{\text {тот }}$, Table S3-S4) in this study falls well into the 447 range reported for boreal wetlands $(2.3-17 \%) .{ }^{7}$ The REFs $(0.1-1.1 \%)$ clearly had $\% \mathrm{MeHg}$ 448 lower than boreal wetlands, while some of the CCs were just as high as the most net methylating 449 and MeHg exporting boreal wetlands. The $k_{m}$ reported for REFs (0.0001-0.007 $\mathrm{d}^{-1}$, Table S5) 450 was clearly much lower than in any of the boreal wetlands, whereas $k_{m}$ values reported for CCs $451\left(0.014-0.58 \mathrm{~d}^{-1}\right)$ were well in the range reported for boreal wetlands $\left(0.002-0.10 \mathrm{~d}^{-1}\right) .^{7}$ The most 452 highly methylating CC soils showed five times higher $k_{m}$ than the most highly methylating boreal 453 wetlands. Thus, while mature coniferous reference stands may show low rates of Hg methylation 454 and $\mathrm{MeHg}$ soil pools are low, rates may locally increase tremendously after clear-cutting at $\mathrm{Hg}$ 455 methylation hot-spots and $\mathrm{O}$ horizon pools of $\mathrm{MeHg}$ may reach levels similar to the highest net 456 methylating wetlands. The same stimulatory factors: availability of electron donors, acceptors 457 and nutrients suggested to explain hot-spots for $\mathrm{Hg}$ methylation in the transition zone between 
458 uplands and fen wetlands ${ }^{52}$ and in fens with intermediate nutrient status, ${ }^{6,7}$ may apply also for

459 hot-spots after forest clear-cutting.

460 Since there were no indications that differences in $\mathrm{Hg}$ speciation or availability of

461 electron acceptors control the large differences in the concentrations of MeHg build-up in CC

462 soils and the much higher $k_{m}$, as compared to REFs, we argue that the increased water saturation

463 of soil, in concert with readily available organic electron donors ${ }^{28,44}$ are the main factors

464 responsible for building up an active community of $\mathrm{Hg}$ methylating microbes in $\mathrm{O}$ horizons of

465 hillslope soils after forest clear-cut.

Environmental implications of forest management practices. Of utmost importance to

467 minimize $\mathrm{MeHg}$ export to aquatic ecosystems would be to avoid connecting $\mathrm{Hg}$ methylation hot-

468 spots established in lower sections in local discharge areas of hillslopes with draining streams

469 during clear-cutting operations. Connectivity is provided by driving tracks and by digging new or

470 clearing old ditches. These activities therefore should be minimized until a new forest stand has

471 been established. Previous studies suggest it may take 10 years or longer until the effect of forest

472 harvest on $\mathrm{MeHg}$ export returns back to pre-harvest levels. ${ }^{18,20}$ Whole-tree harvest, where some

473 of the organic clear-cut debris is removed, may decrease this time window by limiting the input

474 of readily available electron donors in form of organic debris to anaerobic bacteria. Although

475 peaty soils located in the riparian zone along streams may be less prone to increased $\mathrm{MeHg}$ net

476 formation after forest harvest, the general recommendation to avoid driving close to streams ${ }^{19,34}$

477 would result in minimum export of $\mathrm{MeHg}$ from these regularly $\mathrm{Hg}$ methylating soils. 


\section{Supporting Information}

482 The supporting information is available free of charge on the ACS Publications website. SI 483 contains Text S1-S3, Figure S1-S3 and Tables S1-S4.

\section{ACKNOWLEDGMENT}

486 We thank the landowner Holmen Skog AB for hosting the research. Funding was provided by the 487 Swedish Research Council for Environment and Spatial Planning (FORMAS, 29-2009-1207), the 488 Swedish Forest Society Foundation (Skogssällskapet, 1011-85/150-7) and CMF-Umeå 489 (No.0822333) to U.S and the Kempe Foundation (SMK-1243, SMK-2745) to E.B and U.S, and 490 ETH Zurich (grant no. 1509-2) to J.W.

\section{REFERENCES}

493 (1) Åkerblom, S.; Nilsson, M. ;Yu, J. ; Ranneby, B.; Johansson, K. Temporal change

494 estimation of mercury concentrations in northern pike (Esox lucius L.) in Swedish lakes, $495 \quad$ Chemosphere 2012, 86, 439-45.

496 (2) Gandhi, N.; Tang, R.W.K.; Bhavsar, S.P.; Arhonditsis, G.B. Fish mercury levels appear to be 497 increasing lately: a report from 40 years of monitoring in the province of Ontario, 498 Canada, Environ. Sci. Technol., 2014, 46, 8052-60. 
502 (3) Lindquist, O.; Johansson, K.; Aastrup, M.; Andersson, A.; Bringmark, L.; Hovsenius, G.; Håkanson, L.; Iverfeldt, Å.; Meili, M.; Timm, B. Mercury in the Swedish environment recent research on causes, consequences and corrective methods. Water, Air, \& Soil Pollut. 1991, 55, 221-251.

(4) Rudd, J.W.M. Sources of methyl mercury to freshwater ecosystems: Review. Wat. Air Soil Pollut. 1995, 80, 697-713.

(5) St. Louis, V. L.; Rudd, J. W. M.; Kelly, C. A.; Beaty, K. G.; Flett, R. J.; Roulet, N. T. Production and loss of methylmercury and loss of total mercury from boreal forest

(6) Tjerngren, I.; Meili, M.; Björn, E.; Skyllberg, U. Boreal wetlands as sources and sinks of catchments containing different types of wetlands. Environ. Sci. Technol. 1996, 30, 2719-

(7) Tjerngren, I.; Karlsson, T.; Björn, E.; Skyllberg, U., Potential Hg methylation and MeHg demethylation rates related to the nutrient status of different boreal wetlands. methyl mercury in relation to soil acidity, $\mathrm{C} / \mathrm{N}$ ratio, and small-scale flooding. Environ.

(8) Kronberg, R.-M.; Tjerngren, I.; Drott, A.; Björn, E.; Skyllberg, U. Net degradation of

(9) Jensen, S.; Jernelöv, A. Biological methylation of mercury in aquatic organisms Nature,

522 (10) Compeau, G.C.; Bartha, R. Sulfate-reducing bacteria: principal methylators of mercury in anoxic estuarine sediment. Appl. Environ. Microbiol. 1985, 50, 498-502. 
525 (11) Fleming, E.J.; Mack, E.E.; Green, P.G.; Nelson, D.C. Mercury methylation from

(12) Hamelin, S.P.; Amyot, M.; Barkay, T.; Wang, Y.; Planas, D. Methanogens: Principal methylators of mercury in lake periphyton. Environ. Sci. Technol. 2011, 45, 7693-7700.

(13) Parks, J.M.; Johs, A.; Podar, M.; Bridou, R.; Hurt, R.A.; Smith, S.D.; Tomanicek, S.J.; Qian, Y.; Brown, S.D.; Brandt, C.C.; Palumbo, A.V.; Smith, J.C.; Wall, J.D.; Elias, D.A.; Liang, L. The genetic basis for bacterial mercury methylation. Science, 2013, 339, 13321335.

(14) Gilmour, C.C.; Podar, M.; Bullock, A.L.; Graham, A.M.; Brown, S.; Somenahally, A.C.; Johs, A.; Hurt, R.; Bailey, K.L.; Elias, D. Mercury methylation by novel microorganisms from new environments. Environ Sci Technol, 2013, 47, 11810-11820.

(16) Garcia, E.; Carignan, R. Impact of wildfire and clear-cutting in the boreal forest on methyl mercury in zooplankton. Can. J. Fish. Aquat. Sci. 1999, 56, 339-345.

(15) Grigal, D. F. Mercury sequestration in forests and peatlands: a review. J. Environ. Qual., 2003, 32, 393-405. boreal lakes with logged, burned, or undisturbed catchments, Can. J. Fish. Aquat. Sci. $\mathbf{2 0 0 0}, 57,129-135$. 
548 (19) Bishop, K. et al. (authors). The effects of forestry on Hg bioaccumulation in nemoral/boreal waters and recommendations for good silvicultural practice, Ambio 2009, 38, 373-80.

(20) Skyllberg, U.; Westin, M. B.; Meili, M.; Bjorn, E. Elevated concentrations of methyl mercury in streams after forest clear-cut: a consequence of mobilization from soil or new

(21) Eklöf, K.; Schelker, J.; Sorensen, R.; Meili, M.; Laudon, H.; von Brömssen, C.; Bishop K. Impact of forestry on total and methyl-mercury in surface waters: Distinguishing effects of logging and site preparation. Environ. Sci. Technol. 2014, 48, 4690-4698.

(22) Kronberg, R-M.; Drott, A.; Jiskra, M.; Wiederhold, J.G.; Björn, E.; Skyllberg, U. Forest harvest contribution to Boreal freshwater methyl mercury load. Global Biogeochem. Cycles 2016, 30, 825-843.

(23) De Wit, H.A.; Granhus,A.; Lindholm, M.; Kainz, M.J.; Lin, Y.; Braaten, H.F.V.; Blaszczak, J. Forest harvest effects on mercury in streams and biota in Norwegian boreal catchments, For. Ecol. Man., 2013, 324, 52-63.

(24) Kreutzweiser, D.P.; Hazlett, P.W.; Gunn, J.M. Logging impacts on the biogeochemistry of boreal forest soils and nutrient export to aquatic systems: A review. Environ. Rev. 2008, $16,157-179$.

(25) Bosch, J.; Hewlett, J.A. A review of catchment experiments to determine the effect of vegetation changes on water yield and evapotranspiration. J. Hydrol. 1982, 55, 3-23.

(26) Rosén, K.; Aronson, J.; Eriksson, H. Effects of clear-cutting on stream water quality in forest catchments in central Sweden. For. Ecol. Manage. 1996, 83, 237-244. 
571 (27) Ullrich, S. M.; Tanton, T. W.; Abdrashitova, S. A. Mercury in the aquatic environment: A review of factors affecting methylation. Crit. Rev. Environ. Sci. Technol. 2001, 31, 241-

(28) Hall, B. D.; St Louis, V. L.; Rolfhus, K. R.; Bodaly, R. A.; Beaty, K. G.; Paterson, M. J.; Cherewyk, K. A. Impacts of reservoir creation on the biogeochemical cycling of methyl mercury and total mercury in Boreal Upland Forests. Ecosystems 2005, 8, 248-266.

(29) Schelker, J.; Grabs, T.; Bishop, K.; Laudon, H. Drivers of increased organic carbon concentrations in stream water following forest disturbance: separating effects of changes in flow pathways and soil warming. J. Geophys. Res. 2013, 118, 1814-1827.

(30) Mazur, M.; Mitchell, C.P.J.; Eckley, C.S.; Eggert, S.L.; Kolka, R.K.; Sebestyen, S.D.; intensity: a field manipulation experiment. Sci. Tot. Environ. 2014, 496, 678-687.

(33) Jiskra, M., Wiederhold, J.G; Skyllberg, U; Kronberg, R-.M.; Hjdas, I.; Kretzschmar, R.
Mercury deposition and re-emission pathways in boreal forest soils investigated with Hg

(33) Jiskra, M., Wiederhold, J.G; Skyllberg, U; Kronberg, R-.M.; Hjdas, I.; Kretzschmar, R.
Mercury deposition and re-emission pathways in boreal forest soils investigated with Hg isotope signatures. Environ. Sci. Technol. 2015, 49, 7188-7196.

(31) IUSS Working Group WRB. World Reference Base for Soil Resources 2014, update 2015 International soil classification system for naming soils 534 and creating legends for soil maps. World Soil Resources Reports 2015, No. 106. FAO, Rome.

(32) Hintelmann, H.; Keppel-Jones, K.; Evans, R.D. Constants of mercury methylation and demethylation rates in sediments and comparison of tracer and ambient mercury availability. Environ. Tox. Chem. 2000, 19, 2204-2211.

(34) Eklöf,K.; Lidskog, R.; Bishop, K. Managing Swedish forestry’s impact on mercury in fish: defining the impact and mitigation measures. Ambio 2016, 45 (Suppl. 2), S163-S174. 
594 (35) McClain, M.E.; Boyer, E.W.; Dent, C.L.; Gergel, S.E.; Grimm, N.B.; Groffman, P.M.; Hart, 595 S.C.; Harvey, J.W.; Johnston, C.A.; Mayorga, E.; McDowell, W.H; Pinay, G. Biogeochemical hot spots and hot moments at the interface of terrestrial and aquatic ecosystems. Ecosystems 2003, 5, 301-312.

(36) Jonsson, S.; Skyllberg, U.; Nilsson, M.B.; Westlund, P-.O.; Shchukarev, A.; Lundberg, E.; Björn, E. Mercury methylation rates for geochemically relevant $\mathrm{Hg}^{\mathrm{II}}$ species in sediments. Environ. Sci. Technol. 2012, 46, 11653-11659.

(37) Skyllberg, U., Xia, K., Bloom, P.R., Nater, E.A., and Bleam, W. F. Binding of mercury (II) To reduced sulfur in soil organic matter along upland-peat soil transects. J. Environ. Qual. 2000, 29, 855-865. in soil organic matter: EXAFS evidence for linear two-coordination with reduced sulphur groups. Environ. Sci. Technol. 2006, 40, 4147-4180.

(39) Lovley, D.R.; Phillips, E.J.P. Novel mode of microbial energy metabolism: organic carbon oxidation coupled to dissimilatory reduction of iron or manganese. Appl Environ Microbiol, 1988, 54, 1472-1480.

(40) Taylor, B.; Oremland, R. Depletion of adenosine triphosphate in Desulfovibrio by oxyanions of group VI elements. Curr Microbiol, 1979, 3, 101-103.

(41) Bowler, M.W.; Montgomery, M.G.; Leslie, A.G.; Walker, J. E. How azide inhibits ATP

614 (42) Bishop, K.; Lee, Y-.H.; Pettersson, C.; Allard, B. terrestrial sources of methylmercury in surface waters: the importance of the riparian zone on the Svartberget catchment. Wat., Air Soil Pollut. 1995, 80, 435-444. 
617 (43) Bishop, K.H.; Grip, H.; O’Neill, A. The origins of acid runoff in a hillslope during storm events. J. Hydrol. 1990, 116, 35-61.

(44) Rolfhus, K.R., Hurley, J.P., Bodaly, R.A., Perrine, G. Production and retention of methylmercury in inundated boreal forest soil. Environ. Sci. Technol. 2015, 49, 34823489.

(45) Qian, J.; Skyllberg, U.; Bloom, P.R.; Bleam, W.F.; Frech, W.; Petit,P-E. Bonding of methyl mercury to reduced sulfur groups in soil and stream organic matter as determined by x-ray absorption spectroscopy and binding affinity studies. Geochim. Cosmochim.

(46) Nykvist, N.; Rosén, K. Effect of clear-felling and slash removal on the acidity of northern Acta 2002, 66, 3873-3885.

(47) Urban, N.R.; Ernst, K.; Bernasconi, S. Addition of sulfur to organic matter during early diagenesis of lake sediments. Geochim. Cosmochim. Acta. 1999, 63, 837-853. Differentiated availability of geochemical mercury pools controls methylmercury levels in estuarine sediment and biota. Nat. Commun. 2014, 5, 4624. 
640 (51) Drott, A.; Lambertsson, L.; Björn, E.; Skyllberg, U. Do potential methylation rates reflect 641 accumulated methyl mercury in contaminated sediments? Environ. Sci. Technol. 2008,

643 (52) Mitchell, C.P.J.; Branfireun, B.A.; Kolka, R.K. Spatial characteristics of net methylmercury production hot spots in peatlands. Environ. Sci. Technol. 2008, 42, 1010-1016.

(53) St. Louis, V.L.; Rudd, J.W.M.; Kelly, C.A.; Bodaly, R.A.; Paterson, M.J.; Beaty, K.G.; Hesslein, R.H.; Heyes, A.; Majewski, A.R. The rise and fall of mercury methylation in an experimental reservoir. Environ. Sci. Technol. 2004, 38, 1348-1358.

(54) Skyllberg, U.; Qian, J.; Frech, W.; Xia, K.; Bleam, W.F. Distribution of mercury, methyl mercury and organic sulfur species in soil, soil solution and stream of a boreal forest catchment. Biogeochem. 2003, 64, 53-76.

(55) Skyllberg, U. Competition among thiols, inorganic sulfides and polysulfides for $\mathrm{Hg}$ and $\mathrm{MeHg}$ in wetland soils and sediments under suboxic conditions - illumination of controversies and implications for MeHg net production. J. Geophys. Res. 2008, 113, G00C03.

(56) Zhang, T.; Kucharzyk, K.H.; Kim, B.; Deshusses, M.A.; Hsu-Kim, H. net methylation of mercury in estuarine sediment mesocosms amended with dissolved, nanoparticulate, and microparticulate mercuric sulfide. Environ. Sci. Technol. 2014, 48, 9133-9141. molecular mass thiols and its importance for mercury methylation. Department of Chemistry. Umeå University. Doctoral Thesis. 2016. ISBN:978-91-7601-469-1 
663 TOC/Abstract graphics

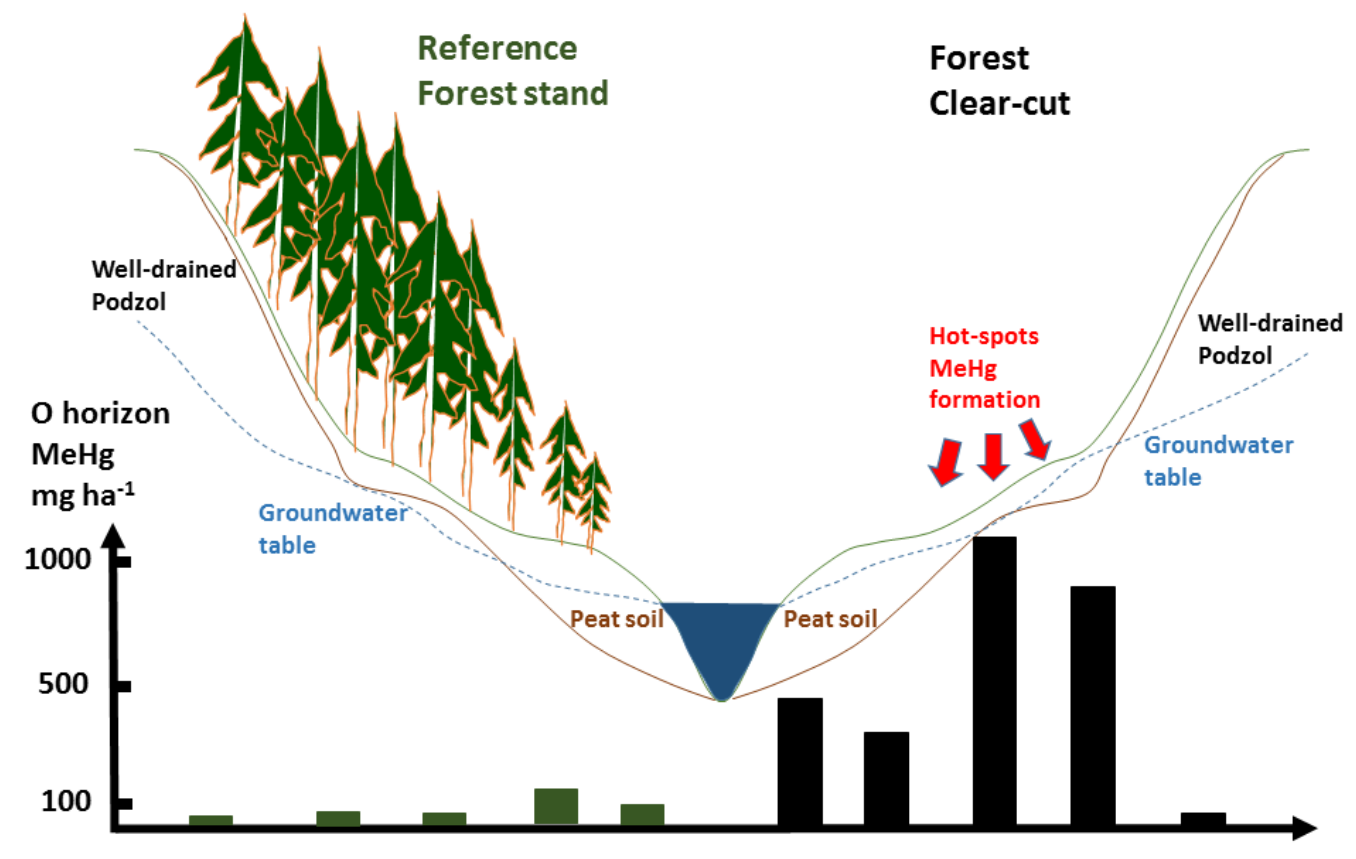

664 